\title{
Molecular genetics of Ewing sarcoma, model systems and finding novel (immuno-) therapeutic targets
}

\author{
Wietske van der Ent ${ }^{1}$, Laurens G.L. Sand ${ }^{2}$, Pancras C.W. Hogendoorn ${ }^{3}$ \\ IInstitute of Biology, Leiden University, Leiden $2311 \mathrm{EZ}$, The Netherlands. \\ 2Department of Bone Marrow Transplantation and Cellular Therapy, St. Jude Children's Research Hospital, Memphis, TN 38105, USA \\ ${ }^{3}$ Department of Pathology, Leiden University Medical Center, Leiden 2333 ZA, The Netherlands.
}

Correspondence to: Prof. Pancras C.W. Hogendoorn, Department of Pathology, Leiden University Medical Center, Albinusdreef 2 , Leiden 2333 ZA, The Netherlands. E-mail: p.c.w.hogendoorn@lumc.nl

How to cite this article: van der Ent W, Sand LGL, Hogendoorn PCW. Molecular genetics of Ewing sarcoma, model systems and finding novel (immuno-) therapeutic targets. J Trans/ Genet Genom 2018;2:10. https://doi.org/10.20517/jtgg.2018.09

Received: 11 May 2018 First Decision: 15 May 2018 Revised: 20 May 2018 Accepted: 21 May 20188 Published: 16 Jul 2018

Science Editor: David N. Cooper Copy Editor: Jun-Yao Li Production Editor: Huan-Liang Wu

\begin{abstract}
Ewing sarcoma (EWS) is a bone- and soft tissue tumour affecting primarily children and young adults. A quarter of patients present with metastases at the time of diagnosis and have a poor outlook in terms of overall survival. Efforts are made across the field to gain deeper insight in the genetics of this enigmatic neoplasm. EWS is characterized by presence of an oncogenic translocation gene, EWSRT-ETS. In addition, there are a limited number of known recurrent DNA copy number variations and mutations. Subsequent of the above, the epigenetic profile of EWS is subject of interest. In this review, we summarize the current available knowledge on the genetics underpinning EWS, explore the current knowledge of its epigenetic profile, discuss in vitro and in vivo model systems, and explore the unravelling knowledge of potential targets for treatment including recent insights into potential immunotherapy.
\end{abstract}

Keywords: Bone neoplasm, Ewing sarcoma, genetic translocation, DNA copy number variation, mutation

\section{INTRODUCTION}

Ewing sarcoma (EWS) is the second most common bone- and soft tissue sarcoma affecting children and young adults. It presents microscopically as a tumour consisting of rather uniform small blue round cells expressing CD99 on its cell membrane, usually with glycogen deposition in its cytoplasm, and is characterized by an EWSR1-ETS translocation. Peak incidence is between 10 and 20 years old, with a slight majority of male patients (1.4:1 ratio $)^{[1]}$. EWS was first described by James Ewing in 1921 as a "diffuse endothelioma of bone ${ }^{y[2]}$, however, the cell of origin of EWS has long been a subject of debate. Based on ultrastructural

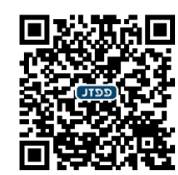


features and biomarkers, in the past it has been ascribed to endothelial, reticuloendothelial, hematopoietic, neural crest and mesenchymal cells ${ }^{[3-5]}$. Currently, the view is that EWS arises from a progenitor or stem cell derived from neural crest or mesenchymal cells. The main sites of involvement are the long bones, pelvis and ribs ( $\sim 85 \%$ of all cases), and lower extremities and the paravertebral region in cases of extra skeletal involvement $(\sim 15 \%)^{[1,6]}$.

Overall survival rates of EWS patients with localised disease have starkly improved since the introduction of systemic therapy to the treatment regime ${ }^{[7]}$. Patients with localised disease currently have an overall event free survival of $60 \%-70 \%{ }^{[8]}$. In a quarter of patients, metastatic disease is observed at the time of diagnosis. These patients have an unfavourable prognosis, with overall event free survival of $20 \%-30 \%{ }^{[9-12]}$. Patients who solely have lung-metastases seem to fare somewhat better than patients with metastases in bone or bonemarrow $^{[13,14]}$.

Standard protocol for treatment of EWS upon diagnosis is chemotherapy followed by surgical resection and/ or radiotherapy ${ }^{[15,16]}$. In Europe, the chemotherapeutic regime consists of multiple cycles of vincristine, ifosfamide, doxorubicin and etoposide ${ }^{[16,17]}$.

\section{GENETIC ALTERATIONS}

\section{Chromosomal translocations}

In $85 \%$ of all EWS cases, there is a reciprocal $\mathrm{t}(11 ; 22)(\mathrm{q} 24 ; \mathrm{q} 12)$ translocation, merging ES Breakpoint region 1 (EWSR1) to Friend leukaemia virus integration site 1 (FLI1 ${ }^{[18]}$. The fusion of EWSR1 with $E R G, \mathrm{t}(21 ; 22)$ (q11;q12), makes up for another $10 \%$ of EWS cases ${ }^{[1,20]}$. Both FLI1 and ERG are members of the erythroblast transformation-specific (ETS) transcription factor family and share a conserved DNA binding domain structure. Fusion of the N-terminal region of EWSR1, which contains a strong transcriptional activation domain ${ }^{[21,22]}$, and these DNA binding domains causes aberrant transcription of a multitude of genes. Additionally, EWSR1-ETS is known to affect epigenetic programs ${ }^{[23,24]}$, splicing ${ }^{[25,26]}$, and metabolic activity ${ }^{[27]}$ of EWS. Oncogenic fusions between ETS genes and transcriptional activators are not unique to EWS: in 50\%-70\% of prostate cancers, similar chromosomal rearrangements are found ${ }^{[28]}$.

The breakpoint position varies, and commonly occurs between exons 7-11 for EWSR1 and exons 4-9 for FLI1, leading to variations in fusion types between patients with EWSR1-FLI1. The most common type is a fusion between EWSR1 exons 1-7 and FLI1 exons 6-9, a type 1 fusion, or EWSR1 exons 1-7 and FLI1 exons 5-9, a type 2 fusion. The effect of these variations in the oncogene on its function has been debated. While some studies observe differences in malignancy between fusion types ${ }^{[29,30]}$, a European prospective trial found no prognostic significance between them ${ }^{[31]}$. Different fusion types were shown to have a different dependence on various proteins of the splicing machinery, so inhibition of splicing factors may have therapeutic value in some cases of $\mathrm{EWS}^{[32]}$.

As the only consistent genetic alteration, among the very few found in EWS in general, EWSR1-FLI1 has been the main player in the attempts to develop in vitro and in vivo models for the disease. However, development of transgenic mouse-models is hampered by toxicity of EWSR1-FLI1 to most cells ${ }^{[33]}$. Additional genetic variations may be needed to create a permissive environment, implied by the bias of disease occurrence in Caucasians ${ }^{[1]}$. A recent GWAS identified 3 EWS-associated single nucleotide polymorphisms (SNPs), near EGR2, BMF and TARDBP genes ${ }^{[34]}$. At the locus near EGR2, the causative SNP links two GGAA repeat stretches ${ }^{[35]}$. In addition to classic ETS transcription factor binding sites, EWSR1-FLI1 preferentially binds to such stretches of GGAA repeats, where its activity increases with the increase of amount of repeats ${ }^{[36,37]}$.

In addition to the more common EWSR1-FLI1 and EWSR1-ERG translocation events, other fusions between members of the TET family of proteins (including EWSR1 and FUS) and members of the ETS transcription 
Table 1. Rare chromosomal rearrangements found in Ewing sarcoma

\begin{tabular}{|c|c|c|c|}
\hline Rearrangement types & Fusion gene & Chromosomal rearrangement & References \\
\hline \multirow{5}{*}{$\begin{array}{l}\text { Rearrangement between TET } \\
\text { and ETS family of genes }\end{array}$} & EWSR1-ETV1 & $\mathrm{t}(7 ; 22)(\mathrm{p} 22 ; q 12)$ & Jeon et al..$^{[40]}$ \\
\hline & EWSR1-ETV4 & $\mathrm{t}(17 ; 22)(\mathrm{q} 21 ; \mathrm{q} 12)$ & Urano et al. ${ }^{[41]}$ \\
\hline & EWSR1-FEV & $\mathrm{t}(2 ; 22)(q 35 ; q 12)$ & Peter et al..$^{[42]}$ \\
\hline & FUS-ERG & $\mathrm{t}(16 ; 21)(\mathrm{p} 11 ; \mathrm{q} 22)$ & Shing et al..$_{[43]}^{[1}$ \\
\hline & FUS-FEV & $\mathrm{t}(2 ; 16)(q 35 ; p 11)$ & $\mathrm{Ng}$ et al. ${ }^{[44]}$ \\
\hline \multirow{5}{*}{$\begin{array}{l}\text { Rearrangement between TET } \\
\text { and non-ETS family of genes }\end{array}$} & EWSR1-NFATC2 & $\mathrm{t}(20 ; 22)(\mathrm{q} 13 ; q 12)$ & Szuhai et $a{ }^{\left[{ }^{[45]}\right.}$ \\
\hline & EWSR1-POU5F1 & $\mathrm{t}(20 ; 22)(\mathrm{p} 21 ; \mathrm{q} 12)$ & Yamaguchi et al. ${ }^{[46]}$ \\
\hline & EWSR1-SMARCA5 & $\mathrm{t}(4 ; 22)(\mathrm{q} 31 ; \mathrm{q} 12)$ & Sumegi et al. ${ }^{[47]}$ \\
\hline & EWSR1-PATZ & $\mathrm{t}(1 ; 22)(\mathrm{p} 36.1 ; \mathrm{q} 12)[$ with inv(22)] & Mastrangelo et al. ${ }^{[48]}$ \\
\hline & EWSR1-SP3 & $t(2 ; 22)(q 31 ; q 12)$ & Wang et $a l^{[49]}$ \\
\hline \multirow{6}{*}{$\begin{array}{l}\text { Rearrangement between non- } \\
\text { TET and non-ETS family of } \\
\text { genes }\end{array}$} & $C I C-D U X 4$ & $\mathrm{t}(4 ; 19)(\mathrm{q} 35 ; \mathrm{q} 13)$ & Kawamura-Saito et al. ${ }^{[38}$ \\
\hline & CIC-FOXO4 & $t(X ; 19)(q 13 ; q 13.3)$ & $\begin{array}{l}\text { Brohl et al. }{ }^{[50]} \\
\text { Sugita et al. } .^{[51]}\end{array}$ \\
\hline & BCOR-CCNB3 & $\operatorname{inv}(X)(p 11.4 p 11.22)$ & Pierron et al. ${ }^{[39]}$ \\
\hline & BCOR-MAML3 & $\mathrm{t}(\mathrm{x} ; 4)(\mathrm{p} 11.4 ; \mathrm{q} 31.1)$ & Specht et al. ${ }^{[52]}$ \\
\hline & ZCЗН7B-BCOR & & Specht et $a{ }^{\left[{ }^{[52]}\right.}$ \\
\hline & CRTC1-SS18 & & Alholle et $a !_{.[53]}$ \\
\hline
\end{tabular}

factor family have been identified. In some cases, tumours with histological, radiological and clinical features are identified without rearrangement between TET members and ETS members. These "Ewing-like" tumours do bear other chromosomal translocations, such as the CIC-DUX4 or BCOR-CCNB ${ }^{[38,39]}$. An overview of these rarer types of translocation found in EWS is given in Table $1^{[38-53]}$.

\section{Copy number alterations}

Besides the characteristic EWSR1-ETS translocation, chromosomal copy number alterations have been described with various implications for clinical outcome. Trisomy of chromosome 8 occurs in about 35\%-45\% of all cases, gain of chromosome 12 in $25 \%-33 \%{ }^{[54-57]}$; these gains can occur together or separately, and are more likely to be found in relapses than in primary tumours. Chromosome 8 gain confers no significant prognostic value, while gain of chromosome 12 has been reported to associate with adverse effects in patients with localised disease ${ }^{[58]}$. Gain of chromosome 2 is primarily found in localised tumours and may indicate a positive prognosis ${ }^{[59]}$.

An unbalanced der(16)t $(1 ; 16)$ translocation leading to partial tri- or tetrasomy of $1 \mathrm{q}$ and partial monosomy of 16 is found in $10 \%-30 \%$ of cases ${ }^{[54,57,60,61]}$. Gain of $1 \mathrm{q}$ was repeatedly correlated to an adverse clinical pronosis. Overexpression of cell division cycle protein 2 (CDT2), encoding a protein involved in the ubiquitin ligase activity and DNA damage repair, is suggested to underlie this aggressive phenotype ${ }^{[62]}$.

After $16 \mathrm{q}$, loss of $9 \mathrm{p} 21$ is most frequently observed, and results in a poor clinical outcome ${ }^{[63]}$. A reason for this may be the loss of cyclin-dependent kinase Inhibitor $2 \mathrm{~A}(C D K N 2 A)$, present at this locus.

\section{Mutations}

Studies investigating the genomic landscape of EWS highlight the paucity of recurrent somatic mutations in this cancer ${ }^{[50,64,65]}$. Mutation or downregulation of CDKN2A is reported in $10 \%-30 \%$ of EWS cases ${ }^{[66-70]}$. Encoding $\mathrm{P} 16^{\mathrm{INK} 4 \mathrm{~A}}$, loss of $C D K N 2 A$ has been shown to correlate with a poor prognosis ${ }^{[67,68,71]}$, though a later study has stated that it is not a reliable prognostic marker for localised EWS ${ }^{[72]}$. TP53 has also been shown to lead to a poor prognosis, although these mutations are infrequent (less than $15 \%$ of cases) ${ }^{[73]}$, and also a nonreliable prognostic marker for localised disease $\mathrm{e}^{[72]}$.

Inactivating mutations in STAG2 are reported in $9 \%-21 \%$ of EWS cases ${ }^{[74,75]}$, appear to be mutually exclusive with $C D K N 2 A$, while co-associating with TP53 mutations and poor patient prognosis ${ }^{[64]}$. STAG2 is an oncogene recurrently mutated in various cancer types ${ }^{[76]}$. As a member of the cohesion complex, it helps in 
holding chromosome pairs together during cell division, and in the context of cancer also affects genome organization and transcriptional regulation ${ }^{[7]]}$. STAG2 is functionally redundant with STAG1, and depletion of STAG1 resulted in lethality in EWS cells with mutated STAG2, but not in cells with wildtype STAG2, making it an interesting target for therapeutics ${ }^{[78]}$.

\section{Epigenetics}

Despite the quite homogenous genetic make-up of EWS, disease course and presentation varies significantly between patients. This may be attributed to a heterogeneity in the epigenetic profile of EWS tumours. A recent study characterized epigenetic heterogeneity of EWS compared to other tumour types, between different EWS cases, and within individual tumours ${ }^{[79]}$. Based on genome-wide methylation profiles, EWS can be separated from other cancer types and normal tissue. Between patients, no epigenetically defines subtypes are found: samples fall along a mid-to-high range of variation for methylation. Intra-tumour heterogeneity was is also high and varying.

The epigenetic profile of EWS has been directly linked to the activity of EWSR1-FLI ${ }^{[24,80]}$. EWSR1-FLI1 preferentially binds to sites with GGAA repeats, and classical ETS binding sites. At GGAA repeat sites, EWSR1FLI1 acts as an enhancer and causes opening of the chromatin, while at ETS sites it displaces ETS transcription factors, deactivating their enhancer activity.

Efforts are being made to determine epigenetic changes specific to EWS, and the consequences they may have on disease development and progression ${ }^{[81-83]}$. The methylation of NPTX2 or PHF11 has been linked to a less favourable prognosis ${ }^{[82]}$. Another study showed that hypermethylation of PTRF leads to suppression of this tumour suppressor gene, and that reintroduction could lead to p53 activation and subsequent apoptosis ${ }^{[83]}$.

\section{MODEL SYSTEMS}

The relatively simple genetic make-up of EWS makes it an appealing tumour for which to develop a transgenic animal model. However, despite many attempts made, no research group as of yet has been successful $^{[33]}$. Introduction of the EWS oncogene EWSR1-FLI1 in mice has led to embryonic lethality, or development of non-EWS-resembling cancer ${ }^{[84,85]}$. For a comprehensive overview of the efforts made by six independent laboratories to generate a murine model for EWS, we refer to the 2016 publication by Minas et al. ${ }^{[33]}$. In addition to murine models, development of zebrafish transgenic models for EWS has also been attempted. The transient expression of EWSR1-FLI1 in zebrafish embryos led to mitotic defect in the developing embryo ${ }^{[86]}$. A stable transgenic zebrafish line with expression of EWSR1-FLI1 developed solid tumours with histologic features of small round blue cell tumours in a TP53 ${ }^{-/}$background, but the model simultaneously gave rise to malignant peripheral nerve sheet tumours. Another zebrafish model showed that loss of one or both wildtype alleles of the zebrafish EWSR1 orthologue ewsa led to an increase in tumour formation in a $T P 53^{-/}$background, suggesting that EWSR1 deficiency may also contribute to the malignancy of EWSR1-translocation driven tumours ${ }^{[87]}$. Given the lack of transgenic animal models, the EWS research community looks for different models in which to test potential novel therapeutics for the disease.

\section{In vitro models}

In order to test novel therapeutics, classic $2 \mathrm{D}$ culture is widely used. Though rapid and convenient, the contribution of the tumour microenvironment cannot be assessed in these assays, while this could alter drug response significantly. Cells undergo biomechanical stimulation from shear stress due to blood flow, or mechanical forces from surrounding muscle contractility or body impact, and alter their behaviour in response ${ }^{[88,89]}$. EWS cells are no different, and several models have been reported taking this into account ${ }^{[90-92]}$. Shear stress was applied to EWS cells by growing them on 3D scaffolds within a flow perfusion bioreactor. This resulted in an increased production of IGF1, and a shear-stress dependant alteration in response to IGF1-R inhibitors ${ }^{[90]}$. Continued development of this model involves the addition of mesenchymal stem 
cells (MSCs) to the 3D culture, to investigate cross talk between stromal cues and those from biomechanical forces. EWS and MSCs co-cultured in flow perfusion bioreactors stimulated each other's growth and led to altered responses to various inhibitors ${ }^{[91]}$. Another model evaluates the effect of mechanical loading by culturing cells in $3 \mathrm{D}$ scaffolds and subjecting these to cycles of compression ${ }^{[89]}$. This led to an upregulation of RUNX2, linked to drug resistance and poor prognosis when highly expressed in patients.

\section{In vivo models}

To accurately model tumours in a 3D fashion, and assess the effect of the tumour microenvironment on drug response, good animal engraftment models are essential. Earliest xenotransplantation models were injected either subcutaneously or intravenously in nude or $\mathrm{NOD} /$ scid $^{\text {mice }}{ }^{[93-95]}$. Later murine models sought to more closely resemble the native tumour environment by performing orthotopic xenografts in rib bones ${ }^{[96]}$, femur ${ }^{[97]}$, pretibial space ${ }^{[98]}$, and gastrocnemius muscles ${ }^{[99]}$. Not only new compounds are tested but also novel drug delivery methods, such as silk gel to effectuate a sustained release of chemotherapeutics locally ${ }^{[100]}$. Ultrasound visualization is being used for more accurate tissue implantation, as well as identifying early response to treatment ${ }^{[101,102]}$.

In addition to murine models, serval groups have also used zebrafish embryonic xenograft models to test novel therapeutics ${ }^{[95,103-105]}$. Here, cells are injected in the yolk of the embryo, show intra- and extravasation and migration into muscles and fins within 4 days after implantation, making these models interesting for rapid initial screening of a large number of possible therapeutic compounds.

A recent development is the establishment of patient-derived xenograft (PDX) models. A limitation of established cell-lines is that they may have deviated from the original disease during years of culture. With PDX models, pieces of resected tumour are directly implanted in mice, where they will remain until the tumour has reached a size where they need to be respected again and implanted in new mice. This way, the artificial environment of in vitro culture can be avoided. Being a rare tumour, the development of EWS and Ewinglike PDX models is slow, but several models have been established already ${ }^{[106,107]}$.

\section{THERAPEUTIC OPPORTUNITIES}

A limited number of direct targets can be identified from genetics of EWS, with EWSR1-ETS being the most prominent one. Targeting the fusion protein directly has proven to be challenging due to its flexibility, but progress has been made and a phase I clinical trial (NCT02657005) is ongoing with a small molecule inhibitor $^{[108]}$. Aside from targeting the EWSR1-ETS fusion protein directly, inhibiting its dominant direct targets has been investigated as therapeutic alternative, as EWSR1-ETS is a key driver in the epigenetics ${ }^{[23,24]}$, transcription $^{[109]}$, splicing ${ }^{[25,26]}$, and metabolic ${ }^{[27]}$ reprogramming of EWSR1-ETS.

Epigenetic remodelling inhibitors, including HDAC inhibitors and $\mathrm{LSD1}^{[23]}$, with success tested in the preclinical phase, are being tested in clinical trials. EWSR1-ETS influences the transcription at such a level that the cells become very sensitive to genotoxic agents, causing EWS to act like a BRCA1 deficient tumour with impaired homologous recombination, as shown in a recent study ${ }^{[109]}$. The impaired homologous recombination opens therapeutic opportunities for PARP1 inhibitors, and these were effective in the induction of cell death in in vitro and xenograft models. If this translates into the clinic is currently being investigated, as clinical trials with combinations of genotoxic agents and PARP1 inhibitors are ongoing ${ }^{[110,111]}$. Recently a study demonstrated the dysregulation of EWSR1-ETS at protein level and subsequent induction of a high unfolded protein response (UPR). Inhibiting an important protein in this pathway, IRE1 $\alpha$-XBP1 led to reduced cell viability in vitro and in vivo.

\section{IMMUNOTHERAPY IN EWS}

The low mutation rate of EWS suggest that corrective apoptosis pathways, such as the TNF-related apoptosis 
inducing ligand (TRAIL) pathway and the death receptor pathway, are still active ${ }^{[112-117]}$. As a result, the tumour is sensitive to natural killer (NK) and cytotoxic T-cell driven activation of these pathways, leading to cell death. It has been shown that the presence of higher numbers of cytotoxic T-cells in the tumour microenvironment correlated with better overall survival ${ }^{[118]}$.

Considering the sensitivity to NK and cytotoxic T cells, immunotherapy might be a promising therapeutic intervention for EWS. NK clinical trials have started using immunotherapeutic strategies in the treatment of EWS $^{[119-122]}$. They involve treatment with donor NK cells after allogeneic haematopoietic cell transplantation, or after receiving lymphodepleting chemotherapy and IL2, in some cases with a follow-up NK treatment 35 days after haematopoietic cell transplantation. In vitro results show that histone deacetylase inhibitors increase expressions of NKG2D ligands on EWS cells, which can sensitize them for cytolysis via NK cells ${ }^{[123]}$.

Using primed or T cell receptor (TCR)-engineered T cells is a second approach for which EWSR1-ETS would be a very selective target. However, preclinical studies haven't been as successful in vivo as NK immunotherapy, or lacked further follow up ${ }^{[124-127]}$. A limitation of this therapy is the dependency on MHC class I surface expression, which is downregulated by EWS cells ${ }^{[128]}$.

Chimeric antigen receptor (CAR) T cells or NK cells can act independent of MHC class proteins and can selectively be designed for all surface proteins, making it an interesting third approach. In leukaemia and lymphomas, CAR-T cells were very successful in the clinic ${ }^{[129,130]}$. The main target investigated in EWS is the glycolipid $\mathrm{GD}_{2}$, which is expressed in most EWS tumours at varying levels and against which CAR-T cells have been developed ${ }^{[131]}$. Preclinical studies targeting $\mathrm{GD}_{2}$ demonstrated a reduction in tumour volume and a clinical trial with the latest CAR-T cells has been initiated ${ }^{[132]}$. As this therapy can be designed for every surface expressed antigen one can imagine that other targets might be worth investigating such as the recently identified surface protein LINGO ${ }^{[133]}$.

A fourth approach of immunotherapy being investigated for clinical use are cancer vaccines. Higher numbers of CCL21-producing cells at the tumour site was correlated with an improved chemotherapy response and overall survival: this might imply that attraction of dendritic cells and CCR7-positive T cells by a cancer vaccine or a dendritic cell-based cancer vaccine would help to induce long term protection. In addition, cancer vaccines can change the suppressive immune environment by inducing a pro-inflammatory immune response or inhibiting production of immune inhibitory proteins, such as transforming growth factor $\beta 1$ $(\mathrm{TGF}-\beta 1)^{[134-137]}$. The presence of a suppressive immune environment in EWS tumours is illustrated by low the number of infiltrating immune cells, and $\mathrm{T}$ cell infiltration induced upregulation of HLA-G, an immune inhibitory receptor ${ }^{[138]}$. In addition, in xenografts a high number of myeloid-derived suppressor cells were detected in EWS tumours, leading to a reduction in CAR-T cell activity ${ }^{[139]}$. A phase IIb with a TGF- $\beta 1$ inhibiting cancer vaccine is ongoing, but further insight in the immunosuppressive microenvironment of EWS would be beneficial to design an immunotherapy which homes to the tumour site and has long-term tumour specific cytotoxic activity.

\section{CONCLUDING REMARKS}

EWS has a fairly stable genome with a low number of somatic mutations. Aside from the characteristic EWSR1-ETS translocation, only a limited number of recurrent mutations and copy number alterations are found. Deeper insight into the underlying biology of the disease is slow to be obtained, due to its rarity. However, owing to various collaborative efforts and use of state-of-the-art technologies in the field, the needed headway is being made in order to develop novel therapeutics, including potential for immunotherapeutic approaches. Current in vitro and in vivo models including zebrafish models are helpful in the process for better understanding of the molecular genetics of these tumours and maybe more importantly, can act as systems for exploring new therapeutic approaches. 


\section{DECLARATIONS}

\section{Authors' contributions}

Literature research and manuscript writing: van der Ent W, Sand LGL, Hogendoorn PCW

Manuscript editing: van der Ent W, Hogendoorn PCW

\section{Availability of data and materials}

Not applicable.

\section{Financial support and sponsorship}

None.

\section{Conflicts of interest}

All authors declared that there are no conflicts of interest.

\section{Ethical approval and consent to participate}

Not applicable.

\section{Consent for publication}

Not applicable.

\section{Copyright}

(C) The Author(s) 2018.

\section{REFERENCES}

1. Fletcher CDM, Bridge JA, Hogendoorn PCW, Mertens F. WHO classification of tumours of soft tissue and bone, 4th ed. Lyon, France: IARC Press; 2013.

2. $\quad$ Ewing J. Diffuse endothelioma of bone. Proc N Y Path 1921;21:17-24.

3. Lizard-Nacol S, Lizard G, Justrabo E, Turc-Carel C. Immunologic characterization of Ewing's sarcoma using mesenchymal and neural markers. Am J Pathol 1989;135:847-55.

4. Maurer HM. Solid tumors in children. N Engl J Med 1978;299:1345-8.

5. Toomey EC, Schiffman JD, Lessnick SL. Recent advances in the molecular pathogenesis of Ewing's sarcoma. Oncogene 2010;29:4504-16.

6. Geens L, Robays JV, Geert V, der Speeten KV. An unusual location of extraosseous Ewing's sarcoma. Case Rep Oncol 2013;6:293-302.

7. Pizzo PA, Poplack DG. Principles and Practice of Pediatric Oncology, 6th ed. Philadelphia, United States: Wolters Kluwer Health/Lippincott Williams \& Wilkins; 2011.

8. Bacci G, Ferrari S, Longhi A, Donati D, De Paolis M, Forni C, Versari M, Setola E, Briccoli A, Barbieri E. Therapy and survival after recurrence of Ewing's tumors: the Rizzoli experience in 195 patients treated with adjuvant and neoadjuvant chemotherapy from 1979 to 1997. Ann Oncol 2003;14:1654-9.

9. Meyers PA, Krailo MD, Ladanyi M, Chan KW, Sailer SL, Dickman PS, Baker DL, Davis JH, Gerbing RB, Grovas A, Herzog CE, Lindsley KL, Liu-Mares W, Nachman JB, Sieger L, Wadman J, Gorlick RG. High-dose melphalan, etoposide, total-body irradiation, and autologous stem-cell reconstitution as consolidation therapy for high-risk Ewing's sarcoma does not improve prognosis. J Clin Oncol 2001;19:2812-20.

10. Bernstein M, Kovar H, Paulussen M, Randall RL, Schuck A, Teot LA, Juergens H. Ewing's sarcoma family of tumors: current management. Oncologist 2006;11:503-19.

11. Balamuth NJ, Womer RB. Ewing's sarcoma. Lancet Oncol 2010;11:184-92.

12. Hamilton SN, Carlson R, Hasan H, Rassekh SR, Goddard K. Long-term outcomes and complications in pediatric Ewing sarcoma. Am J Clin Oncol 2017;40:423-8.

13. Paulussen M, Ahrens S, Burdach S, Craft A, Dockhorn-Dworniczak B, Dunst J, Fröhlich B, Winkelmann W, Zoubek A, Jürgens H. Primary metastatic (stage IV) Ewing tumor: survival analysis of 171 patients from the EICESS studies. European Intergroup Cooperative Ewing Sarcoma Studies. Ann Oncol 1998;9:275-81.

14. Miser JS, Krailo MD, Tarbell NJ, Link MP, Fryer CJ, Pritchard DJ, Gebhardt MC, Dickman PS, Perlman EJ, Meyers PA, Donaldson SS, Moore S, Rausen AR, Vietti TJ, Grier HE. Treatment of metastatic Ewing's sarcoma or primitive neuroectodermal tumor of bone: evaluation of combination ifosfamide and etoposide--a Children's Cancer Group and Pediatric Oncology Group study. J Clin Oncol 2004;22:2873-6.

15. Drabko K, Raciborska A, Bilska K, Styczynski J, Ussowicz M, Choma M, Wojcik B, Zaucha-Prazmo A, Gorczynska E, Skoczen S, Wozniak W, Chybicka A, Wysocki M, Gozdzik J, Kowalczyk J. Consolidation of first-line therapy with busulphan and melphalan, and autologous stem cell rescue in children with Ewing's sarcoma. Bone Marrow Transplant 2012;47:1530-4.

16. Ladenstein R, Pötschger U, Le Deley MC, Whelan J, Paulussen M, Oberlin O, van den Berg H, Dirksen U, Hjorth L, Michon J, Lewis I, 
Craft A, Jürgens H. Primary disseminated multifocal Ewing sarcoma: results of the Euro-EWING 99 trial. J Clin Oncol 2010;28:3284-91.

17. Juergens C, Weston C, Lewis I, Whelan J, Paulussen M, Oberlin O, Michon J, Zoubek A, Juergens H, Craft A. Safety assessment of intensive induction with vincristine, ifosfamide, doxorubicin, and etoposide (VIDE) in the treatment of Ewing tumors in the EURO-E. W.I.N.G. 99 clinical trial. Pediatr Blood Cancer 2006;47:22-9.

18. Bailly RA, Bosselut R, Zucman J, Cormier F, Delattre O, Roussel M, Thomas G, Ghysdael J. DNA-binding and transcriptional activation properties of the EWS-FLI-1 fusion protein resulting from the $\mathrm{t}(11 ; 22)$ translocation in Ewing sarcoma. Mol Cell Biol 1994;14:3230-41.

19. Zucman J, Melot T, Desmaze C, Ghysdael J, Plougastel B, Peter M, Zucker JM, Triche TJ, Sheer D, Turc-Carel C. Combinatorial generation of variable fusion proteins in the Ewing family of tumours. EMBO J 1993;12:4481-7.

20. Sorensen PH, Lessnick SL, Lopez-Terrada D, Liu XF, Triche TJ, Denny CT. A second Ewing's sarcoma translocation, $\mathrm{t}(21 ; 22)$, fuses the EWS gene to another ETS-family transcription factor, ERG. Nat Genet 1994;6:146-51.

21. Ohno T, Rao VN, Reddy ES. EWS/Fli-1 chimeric protein is a transcriptional activator. Cancer Res 1993;53:5859-63.

22. Arvand A, Denny CT. Biology of EWS/ETS fusions in Ewing's family tumors. Oncogene 2001;20:5747-54.

23. Sankar S, Theisen ER, Bearss J, Mulvihill T, Hoffman LM, Sorna V, Beckerle MC, Sharma S, Lessnick SL. Reversible LSD1 inhibition interferes with global EWS/ETS transcriptional activity and impedes Ewing sarcoma tumor growth. Clin Cancer Res 2014;20:4584-97.

24. Tomazou EM, Sheffield NC, Schmidl C, Schuster M, Schönegger A, Datlinger P, Kubicek S, Bock C, Kovar H. Epigenome mapping reveals distinct modes of gene regulation and widespread enhancer reprogramming by the oncogenic fusion protein EWS-FLI1. Cell Rep 2015;10:1082-95.

25. Tanabe Y, Suehara Y, Kohsaka S, Hayashi T, Akaike K, Mukaihara K, Kurihara T, Kim Y, Okubo T, Ishii M, Kazuno S, Kaneko K, Saito T. IRE1 $\alpha$-XBP1 inhibitors exerted anti-tumor activities in Ewing's sarcoma. Oncotarget 2018;9:14428-43.

26. Selvanathan SP, Graham GT, Erkizan HV, Dirksen U, Natarajan TG, Dakic A, Yu S, Liu X, Paulsen MT, Ljungman ME, Wu CH, Lawlor ER, Üren A, Toretsky JA. Oncogenic fusion protein EWS-FLI1 is a network hub that regulates alternative splicing. Proc Natl Acad Sci U S A 2015;112:E1307-16.

27. Svoboda LK, Teh SSK, Sud S, Kerk S, Zebolsky A, Treichel S, Thomas D, Halbrook CJ, Lee HJ, Kremer D, Zhang L, Klossowski S, Bankhead AR, Magnuson B, Ljungman M, Cierpicki T, Grembecka J, Lyssiotis CA, Lawlor ER. Menin regulates the serine biosynthetic pathway in Ewing sarcoma. J Pathol 2018; doi: 10.1002/path.5085.

28. Kedage V, Selvaraj N, Nicholas TR, Budka JA, Plotnik JP, Jerde TJ, Hollenhorst PC. An interaction with Ewing's sarcoma breakpoint protein EWS defines a specific oncogenic mechanism of ETS factors rearranged in prostate cancer. Cell Rep 2016;17:1289-301.

29. Lin PP, Brody RI, Hamelin AC, Bradner JE, Healey JH, Ladanyi M. Differential transactivation by alternative EWS-FLI1 fusion proteins correlates with clinical heterogeneity in Ewing's sarcoma. Cancer Res 1999;59:1428-32.

30. de Alava E, Panizo A, Antonescu CR, Huvos AG, Pardo-Mindán FJ, Barr FG, Ladanyi M. Association of EWS-FLI1 type 1 fusion with lower proliferative rate in Ewing's sarcoma. Am J Pathol 2000;156:849-55.

31. Le Deley MC, Delattre O, Schaefer KL, Burchill SA, Koehler G, Hogendoorn PC, Lion T, Poremba C, Marandet J, Ballet S, Pierron G, Brownhill SC, Nesslböck M, Ranft A, Dirksen U, Oberlin O, Lewis IJ, Craft AW, Jürgens H, Kovar H. Impact of EWS-ETS fusion type on disease progression in Ewing's sarcoma/peripheral primitive neuroectodermal tumor: prospective results from the cooperative Euro-E. W.I.N.G. 99 trial. J Clin Oncol 2010;28:1982-8.

32. Grohar PJ, Kim S, Rangel Rivera GO, Sen N, Haddock S, Harlow ML, Maloney NK, Zhu J, O’Neill M, Jones TL, Huppi K, Grandin M, Gehlhaus K, Klumpp-Thomas CA, Buehler E, Helman LJ, Martin SE, Caplen NJ. Functional genomic screening reveals splicing of the EWS-FLI1 fusion transcript as a vulnerability in Ewing sarcoma. Cell Rep 2016;14:598-610.

33. Minas TZ, Surdez D, Javaheri T, Tanaka M, Howarth M, Kang HJ, Han J, Han ZY, Sax B, Kream BE, Hong SH, Çelik H, Tirode F, Tuckermann J, Toretsky JA, Kenner L, Kovar H, Lee S, Sweet-Cordero EA, Nakamura T, Moriggl R, Delattre O, Üren A. Combined experience of six independent laboratories attempting to create an Ewing sarcoma mouse model. Oncotarget 2017;8:34141-63.

34. Postel-Vinay S, Véron AS, Tirode F, Pierron G, Reynaud S, Kovar H, Oberlin O, Lapouble E, Ballet S, Lucchesi C, Kontny U, GonzálezNeira A, Picci P, Alonso J, Patino-Garcia A, de Paillerets BB, Laud K, Dina C, Froguel P, Clavel-Chapelon F, Doz F, Michon J, Chanock SJ, Thomas G, Cox DG, Delattre O. Common variants near TARDBP and EGR2 are associated with susceptibility to Ewing sarcoma. Nat Genet 2012;44:323-7.

35. Grünewald TG, Bernard V, Gilardi-Hebenstreit P, Raynal V, Surdez D, Aynaud MM, Mirabeau O, Cidre-Aranaz F, Tirode F, Zaidi S, Perot G, Jonker AH, Lucchesi C, Le Deley MC, Oberlin O, Marec-Bérard P, Véron AS, Reynaud S, Lapouble E, Boeva V, Rio Frio T, Alonso J, Bhatia S, Pierron G, Cancel-Tassin G, Cussenot O, Cox DG, Morton LM, Machiela MJ, Chanock SJ, Charnay P, Delattre O. Chimeric EWSR1-FLI1 regulates the Ewing sarcoma susceptibility gene EGR2 via a GGAA microsatellite. Nat Genet 2015;47:1073-8.

36. Gangwal K, Sankar S, Hollenhorst PC, Kinsey M, Haroldsen SC, Shah AA, Boucher KM, Watkins WS, Jorde LB, Graves BJ, Lessnick SL. Microsatellites as EWS/FLI response elements in Ewing's sarcoma. Proc Natl Acad Sci U S A 2008;105:10149-54.

37. Guillon N, Tirode F, Boeva V, Zynovyev A, Barillot E, Delattre O. The oncogenic EWS-FLI1 protein binds in vivo GGAA microsatellite sequences with potential transcriptional activation function. PLoS One 2009;4:e4932.

38. Kawamura-Saito M, Yamazaki Y, Kaneko K, Kawaguchi N, Kanda H, Mukai H, Gotoh T, Motoi T, Fukayama M, Aburatani H, Takizawa T, Nakamura T. Fusion between CIC and DUX4 up-regulates PEA3 family genes in Ewing-like sarcomas with $\mathrm{t}(4 ; 19)(\mathrm{q} 35 ; \mathrm{q} 13)$ translocation. Hum Mol Genet 2006;15:2125-37.

39. Pierron G, Tirode F, Lucchesi C, Reynaud S, Ballet S, Cohen-Gogo S, Perrin V, Coindre JM, Delattre O. A new subtype of bone sarcoma defined by BCOR-CCNB3 gene fusion. Nat Genet 2012;44:461-6.

40. Jeon IS, Davis JN, Braun BS, Sublett JE, Roussel MF, Denny CT, Shapiro DN. A variant Ewing's sarcoma translocation $(7 ; 22)$ fuses the EWS gene to the ETS gene ETV1. Oncogene 1995;10:1229-34.

41. Urano F, Umezawa A, Yabe H, Hong W, Yoshida K, Fujinaga K, Hata J. Molecular analysis of Ewing's sarcoma: another fusion gene, EWSE1AF, available for diagnosis. Jpn J Cancer Res 1998;89:703-11.

42. Peter M, Couturier J, Pacquement H, Michon J, Thomas G, Magdelenat H, Delattre O. A new member of the ETS family fused to EWS in 
Ewing tumors. Oncogene 1997;14:1159-64.

43. Shing DC, McMullan DJ, Roberts P, Smith K, Chin SF, Nicholson J, Tillman RM, Ramani P, Cullinane C, Coleman N. FUS/ERG gene fusions in Ewing's tumors. Cancer Res 2003;63:4568-76.

44. Ng TL, O’Sullivan MJ, Pallen CJ, Hayes M, Clarkson PW, Winstanley M, Sorensen PH, Nielsen TO, Horsman DE. Ewing sarcoma with novel translocation $\mathrm{t}(2 ; 16)$ producing an in-frame fusion of FUS and FEV. J Mol Diagn 2007;9:459-63.

45. Szuhai K, Ijszenga M, de Jong D, Karseladze A, Tanke HJ, Hogendoorn PC. The NFATc2 gene is involved in a novel cloned translocation in a Ewing sarcoma variant that couples its function in immunology to oncology. Clin Cancer Res 2009;15:2259-68.

46. Yamaguchi S, Yamazaki Y, Ishikawa Y, Kawaguchi N, Mukai H, Nakamura T. EWSR1 is fused to POU5F1 in a bone tumor with translocation $\mathrm{t}(6 ; 22)(\mathrm{p} 21 ; \mathrm{q} 12)$. Genes Chromosomes Cancer 2005;43:217-22.

47. Sumegi J, Nishio J, Nelson M, Frayer RW, Perry D, Bridge JA. A novel t(4;22)(q31;q12) produces an EWSR1-SMARCA5 fusion in extraskeletal Ewing sarcoma/primitive neuroectodermal tumor. Mod Pathol 2011;24:333-42.

48. Mastrangelo T, Modena P, Tornielli S, Bullrich F, Testi MA, Mezzelani A, Radice P, Azzarelli A, Pilotti S, Croce CM, Pierotti MA, Sozzi G. A novel zinc finger gene is fused to EWS in small round cell tumor. Oncogene 2000;19:3799-804.

49. Wang L, Bhargava R, Zheng T, Wexler L, Collins MH, Roulston D, Ladanyi M. Undifferentiated small round cell sarcomas with rare EWS gene fusions: identification of a novel EWS-SP3 fusion and of additional cases with the EWS-ETV1 and EWS-FEV fusions. J Mol Diagn 2007;9:498-509.

50. Brohl AS, Solomon DA, Chang W, Wang J, Song Y, Sindiri S, Patidar R, Hurd L, Chen L, Shern JF, Liao H, Wen X, Gerard J, Kim JS, Lopez Guerrero JA, Machado I, Wai DH, Picci P, Triche T, Horvai AE, Miettinen M, Wei JS, Catchpool D, Llombart-Bosch A, Waldman T, Khan J. The genomic landscape of the Ewing sarcoma family of tumors reveals recurrent STAG2 mutation. PLoS Genet 2014;10:e1004475.

51. Sugita S, Arai Y, Tonooka A, Hama N, Totoki Y, Fujii T, Aoyama T, Asanuma H, Tsukahara T, Kaya M, Shibata T, Hasegawa T. A novel CIC-FOXO4 gene fusion in undifferentiated small round cell sarcoma: a genetically distinct variant of Ewing-like sarcoma. Am J Surg Pathol 2014;38:1571-6.

52. Specht K, Zhang L, Sung YS, Nucci M, Dry S, Vaiyapuri S, Richter GH, Fletcher CD, Antonescu CR. Novel BCOR-MAML3 and ZC3H7B-BCOR gene fusions in undifferentiated small blue round cell sarcomas. Am J Surg Pathol 2016;40:433-42.

53. Alholle A, Karanian M, Brini AT, Morris MR, Kannappan V, Niada S, Niblett A, Ranchère-Vince D, Pissaloux D, Delfour C, MaranGonzalez A, Antonescu CR, Sumathi V, Tirode F, Latif F. Genetic analyses of undifferentiated small round cell sarcoma identifies a novel sarcoma subtype with a recurrent CRTC1-SS18 gene fusion. J Pathol 2018;245:186-96.

54. Mugneret F, Lizard S, Aurias A, Turc-Carel C. Chromosomes in Ewing's sarcoma. II. Nonrandom additional changes, trisomy 8 and der(16) $\mathrm{t}(1 ; 16)$. Cancer Genet Cytogenet 1988;32:239-45.

55. Armengol G, Tarkkanen M, Virolainen M, Forus A, Valle J, Böhling T, Asko-Seljavaara S, Blomqvist C, Elomaa I, Karaharju E, Kivioja AH, Siimes MA, Tukiainen E, Caballín MR, Myklebost O, Knuutila S. Recurrent gains of 1q, 8 and 12 in the Ewing family of tumours by comparative genomic hybridization. Br J Cancer 1997;75:1403-9.

56. Maurici D, Perez-Atayde A, Grier HE, Baldini N, Serra M, Fletcher JA. Frequency and implications of chromosome 8 and 12 gains in Ewing sarcoma. Cancer Genet Cytogenet 1998;100:106-10.

57. Hattinger CM, Rumpler S, Ambros IM, Strehl S, Lion T, Zoubek A, Gadner H, Ambros PF. Demonstration of the translocation der(16) $\mathrm{t}(1 ; 16)(\mathrm{q} 12 ; \mathrm{q} 11.2)$ in interphase nuclei of Ewing tumors. Genes Chromosomes Cancer 1996;17:141-50.

58. Hattinger CM, Pötschger U, Tarkkanen M, Squire J, Zielenska M, Kiuru-Kuhlefelt S, Kager L, Thorner P, Knuutila S, Niggli FK, Ambros PF, Gadner H, Betts DR. Prognostic impact of chromosomal aberrations in Ewing tumours. Br J Cancer 2002;86:1763-9.

59. Brisset S, Schleiermacher G, Peter M, Mairal A, Oberlin O, Delattre O, Aurias A. CGH analysis of secondary genetic changes in Ewing tumors: correlation with metastatic disease in a series of 43 cases. Cancer Genet Cytogenet 2001;130:57-61.

60. Douglass EC, Rowe ST, Valentine M, Parham D, Meyer WH, Thompson EI. A second nonrandom translocation, der(16)t(1;16)(q21;q13), in Ewing sarcoma and peripheral neuroectodermal tumor. Cytogenet Cell Genet 1990;53:87-90.

61. Sandberg AA, Bridge JA. Updates on cytogenetics and molecular genetics of bone and soft tissue tumors: Ewing sarcoma and peripheral primitive neuroectodermal tumors. Cancer Genet Cytogenet 2000;123:1-26.

62. Mackintosh C, Ordóñez JL, García-Domínguez DJ, Sevillano V, Llombart-Bosch A, Szuhai K, Scotlandi K, Alberghini M, Sciot R, Sinnaeve F, Hogendoorn PC, Picci P, Knuutila S, Dirksen U, Debiec-Rychter M, Schaefer KL, de Álava E. 1q gain and CDT2 overexpression underlie an aggressive and highly proliferative form of Ewing sarcoma. Oncogene 2012;31:1287-98.

63. Savola S, Klami A, Tripathi A, Niini T, Serra M, Picci P, Kaski S, Zambelli D, Scotlandi K, Knuutila S. Combined use of expression and CGH arrays pinpoints novel candidate genes in Ewing sarcoma family of tumors. BMC Cancer 2009;9:17.

64. Tirode F, Surdez D, Ma X, Parker M, Le Deley MC, Bahrami A, Zhang Z, Lapouble E, Grossetête-Lalami S, Rusch M, Reynaud S, Rio-Frio T, Hedlund E, Wu G, Chen X, Pierron G, Oberlin O, Zaidi S, Lemmon G, Gupta P, Vadodaria B, Easton J, Gut M, Ding L, Mardis ER, Wilson RK, Shurtleff S, Laurence V, Michon J, Marec-Bérard P, Gut I, Downing J, Dyer M, Zhang J, Delattre O; St. Jude Children's Research Hospital-Washington University Pediatric Cancer Genome Project and the International Cancer Genome Consortium. Genomic landscape of Ewing sarcoma defines an aggressive subtype with co-association of STAG2 and TP53 mutations. Cancer Discov 2014;4:1342-53.

65. Crompton BD, Stewart C, Taylor-Weiner A, Alexe G, Kurek KC, Calicchio ML, Kiezun A, Carter SL, Shukla SA, Mehta SS, Thorner AR, de Torres C, Lavarino C, Suñol M, McKenna A, Sivachenko A, Cibulskis K, Lawrence MS, Stojanov P, Rosenberg M, Ambrogio L, Auclair D, Seepo S, Blumenstiel B, DeFelice M, Imaz-Rosshandler I, Schwarz-Cruz Y, Celis A, Rivera MN, Rodriguez-Galindo C, Fleming MD, Golub TR, Getz G, Mora J, Stegmaier K. The genomic landscape of pediatric Ewing sarcoma. Cancer Discov 2014;4:1326-41.

66. Kovar H, Jug G, Aryee DN, Zoubek A, Ambros P, Gruber B, Windhager R, Gadner H. Among genes involved in the RB dependent cell cycle regulatory cascade, the p16 tumor suppressor gene is frequently lost in the Ewing family of tumors. Oncogene 1997;15:2225-32.

67. Tsuchiya T, Sekine K, Hinohara S, Namiki T, Nobori T, Kaneko Y. Analysis of the p16INK4, p14ARF, p15, TP53, and MDM2 genes and their prognostic implications in osteosarcoma and Ewing sarcoma. Cancer Genet Cytogenet 2000;120:91-8.

68. Wei G, Antonescu CR, de Alava E, Leung D, Huvos AG, Meyers PA, Healey JH, Ladanyi M. Prognostic impact of INK4A deletion in 
Ewing sarcoma. Cancer 2000;89:793-9.

69. Maitra A, Roberts H, Weinberg AG, Geradts J. Aberrant expression of tumor suppressor proteins in the Ewing family of tumors. Arch Pathol Lab Med 2001;125:1207-12.

70. Brownhill SC, Taylor C, Burchill SA. Chromosome 9p21 gene copy number and prognostic significance of p16 in ESFT. Br J Cancer 2007;96:1914-23.

71. Honoki K, Stojanovski E, McEvoy M, Fujii H, Tsujiuchi T, Kido A, Takakura Y, Attia J. Prognostic significance of p16 INK4a alteration for Ewing sarcoma: a meta-analysis. Cancer 2007;110:1351-60.

72. Lerman DM, Monument MJ, Mcllvaine E, Liu XQ, Huang D, Monovich L, Beeler N, Gorlick RG, Marina NM, Womer RB, Bridge JA, Krailo MD, Randall RL, Lessnick SL; Children's Oncology Group Ewing Sarcoma Biology Committee. Tumoral TP53 and/or CDKN2A alterations are not reliable prognostic biomarkers in patients with localized Ewing sarcoma: a report from the Children's Oncology Group. Pediatr Blood Cancer 2015;62:759-65.

73. Huang HY, Illei PB, Zhao Z, Mazumdar M, Huvos AG, Healey JH, Wexler LH, Gorlick R, Meyers P, Ladanyi M. Ewing sarcomas with p53 mutation or p16/p14ARF homozygous deletion: a highly lethal subset associated with poor chemoresponse. J Clin Oncol 2005;23:548-58.

74. Solomon DA, Kim T, Diaz-Martinez LA, Fair J, Elkahloun AG, Harris BT, Toretsky JA, Rosenberg SA, Shukla N, Ladanyi M, Samuels Y, James CD, Yu H, Kim JS, Waldman T. Mutational inactivation of STAG2 causes aneuploidy in human cancer. Science 2011;333:1039-43.

75. Solomon DA, Kim JS, Waldman T. Cohesin gene mutations in tumorigenesis: from discovery to clinical significance. BMB Rep 2014;47:299-310.

76. Lawrence MS, Stojanov P, Mermel CH, Robinson JT, Garraway LA, Golub TR, Meyerson M, Gabriel SB, Lander ES, Getz G. Discovery and saturation analysis of cancer genes across 21 tumor types. Nature 2014;505:495-501.

77. Mazumdar C, Shen Y, Xavy S, Zhao F, Reinisch A, Li R, Corces MR, Flynn RA, Buenrostro JD, Chan SM, Thomas D, Koenig JL, Hong WJ, Chang HY, Majeti R. Leukemia-associated cohesin mutants dominantly enforce stem cell programs and impair human hematopoietic progenitor differentiation. Cell Stem Cell 2015;17:675-88.

78. van der Lelij P, Lieb S, Jude J, Wutz G, Santos CP, Falkenberg K, Schlattl A, Ban J, Schwentner R, Hoffmann T, Kovar H, Real FX, Waldman T, Pearson MA, Kraut N, Peters JM, Zuber J, Petronczki M. Synthetic lethality between the cohesin subunits STAG1 and STAG2 in diverse cancer contexts. Elife 2017;6:e26980.

79. Sheffield NC, Pierron G, Klughammer J, Datlinger P, Schönegger A, Schuster M, Hadler J, Surdez D, Guillemot D, Lapouble E, Freneaux P, Champigneulle J, Bouvier R, Walder D, Ambros IM, Hutter C, Sorz E, Amaral AT, de Álava E, Schallmoser K, Strunk D, Rinner B, LieglAtzwanger B, Huppertz B, Leithner A, de Pinieux G, Terrier P, Laurence V, Michon J, Ladenstein R, Holter W, Windhager R, Dirksen U, Ambros PF, Delattre O, Kovar H, Bock C, Tomazou EM. DNA methylation heterogeneity defines a disease spectrum in Ewing sarcoma. Nat Med 2017;23:386-95.

80. Riggi N, Knoechel B, Gillespie SM, Rheinbay E, Boulay G, Suvà ML, Rossetti NE, Boonseng WE, Oksuz O, Cook EB, Formey A, Patel A, Gymrek M, Thapar V, Deshpande V, Ting DT, Hornicek FJ, Nielsen GP, Stamenkovic I, Aryee MJ, Bernstein BE, Rivera MN. EWSFLI1 utilizes divergent chromatin remodeling mechanisms to directly activate or repress enhancer elements in Ewing sarcoma. Cancer Cell 2014;26:668-81.

81. Patel N, Black J, Chen X, Marcondes AM, Grady WM, Lawlor ER, Borinstein SC. DNA methylation and gene expression profiling of Ewing sarcoma primary tumors reveal genes that are potential targets of epigenetic inactivation. Sarcoma 2012;2012:498472.

82. Alholle A, Brini AT, Gharanei S, Vaiyapuri S, Arrigoni E, Dallol A, Gentle D, Kishida T, Hiruma T, Avigad S, Grimer R, Maher ER, Latif F. Functional epigenetic approach identifies frequently methylated genes in Ewing sarcoma. Epigenetics 2013;8:1198-204.

83. Huertas-Martínez J, Court F, Rello-Varona S, Herrero-Martín D, Almacellas-Rabaiget O, Sáinz-Jaspeado M, Garcia-Monclús S, LagaresTena L, Buj R, Hontecillas-Prieto L, Sastre A, Azorin D, Sanjuan X, López-Alemany R, Moran S, Roma J, Gallego S, Mora J, García Del Muro X, Giangrande PH, Peinado MA, Alonso J, de Alava E, Monk D, Esteller M, Tirado OM. DNA methylation profiling identifies PTRF/ Cavin-1 as a novel tumor suppressor in Ewing sarcoma when co-expressed with caveolin-1. Cancer Lett 2017;386:196-207.

84. Torchia EC, Boyd K, Rehg JE, Qu C, Baker SJ. EWS/FLI-1 induces rapid onset of myeloid/erythroid leukemia in mice. Mol Cell Biol 2007;27:7918-34.

85. Lin PP, Pandey MK, Jin F, Xiong S, Deavers M, Parant JM, Lozano G. EWS-FLI1 induces developmental abnormalities and accelerates sarcoma formation in a transgenic mouse model. Cancer Res 2008;68:8968-75.

86. Embree LJ, Azuma M, Hickstein DD. Ewing sarcoma fusion protein EWSR1/FLI1 interacts with EWSR1 leading to mitotic defects in zebrafish embryos and human cell lines. Cancer Res 2009;69:4363-71.

87. Park H, Galbraith R, Turner T, Mehojah J, Azuma M. Loss of Ewing sarcoma EWS allele promotes tumorigenesis by inducing chromosomal instability in zebrafish. Sci Rep 2016;6:32297.

88. Bacabac RG, Smit TH, Mullender MG, Dijcks SJ, Van Loon JJ, Klein-Nulend J. Nitric oxide production by bone cells is fluid shear stress rate dependent. Biochem Biophys Res Commun 2004;315:823-9.

89. Klein-Nulend J, Bacabac RG, Bakker AD. Mechanical loading and how it affects bone cells: the role of the osteocyte cytoskeleton in maintaining our skeleton. Eur Cell Mater 2012;24:278-91.

90. Santoro M, Lamhamedi-Cherradi SE, Menegaz BA, Ludwig JA, Mikos AG. Flow perfusion effects on three-dimensional culture and drug sensitivity of Ewing sarcoma. Proc Natl Acad Sci U S A 2015;112:10304-9.

91. Santoro M, Menegaz BA, Lamhamedi-Cherradi SE, Molina ER, Wu D, Priebe W, Ludwig JA, Mikos AG. Modeling stroma-induced drug resistance in a tissue-engineered tumor model of Ewing sarcoma. Tissue Eng Part A 2017;23:80-9.

92. Marturano-Kruik A, Villasante A, Yaeger K, Ambati SR, Chramiec A, Raimondi MT, Vunjak-Novakovic G. Biomechanical regulation of drug sensitivity in an engineered model of human tumor. Biomaterials 2018;150:150-61.

93. Scotlandi K, Benini S, Nanni P, Lollini PL, Nicoletti G, Landuzzi L, Serra M, Manara MC, Picci P, Baldini N. Blockage of insulin-like growth factor-I receptor inhibits the growth of Ewing's sarcoma in athymic mice. Cancer Res 1998;58:4127-31.

94. Vormoor J, Baersch G, Decker S, Hotfilder M, Schäfer KL, Pelken L, Rübe C, Van Valen F, Jürgens H, Dockhorn-Dworniczak B. 
Establishment of an in vivo model for pediatric Ewing tumors by transplantation into NOD/scid mice. Pediatr Res 2001;49:332-41.

95. Franzius C, Hotfilder M, Poremba C, Hermann S, Schäfers K, Gabbert HE, Jürgens H, Schober O, Schäfers M, Vormoor J. Successful highresolution animal positron emission tomography of human Ewing tumours and their metastases in a murine xenograft model. Eur J Nucl Med Mol Imaging 2006;33:1432-41.

96. Wang YX, Mandal D, Wang S, Hughes D, Pollock RE, Lev D, Kleinerman E, Hayes-Jordan A. Inhibiting platelet-derived growth factor $\beta$ reduces Ewing's sarcoma growth and metastasis in a novel orthotopic human xenograft model. In Vivo 2009;23:903-9.

97. Vormoor B, Knizia HK, Batey MA, Almeida GS, Wilson I, Dildey P, Sharma A, Blair H, Hide IG, Heidenreich O, Vormoor J, Maxwell RJ, Bacon CM. Development of a preclinical orthotopic xenograft model of Ewing sarcoma and other human malignant bone disease using advanced in vivo imaging. PLoS One 2014;9:e85128.

98. Goldstein SD, Hayashi M, Albert CM, Jackson KW, Loeb DM. An orthotopic xenograft model with survival hindlimb amputation allows investigation of the effect of tumor microenvironment on sarcoma metastasis. Clin Exp Metastasis 2015;32:703-15.

99. Hong SH, Tilan JU, Galli S, Izycka-Swieszewska E, Polk T, Horton M, Mahajan A, Christian D, Jenkins S, Acree R, Connors K, Ledo P, Lu C, Lee YC, Rodriguez O, Toretsky JA, Albanese C, Kitlinska J. High neuropeptide Y release associates with Ewing sarcoma bone dissemination - in vivo model of site-specific metastases. Oncotarget 2015;6:7151-65.

100. Harris JC, Coburn JM, Kajdacsy-Balla A, Kaplan DL, Chiu B. Sustained delivery of vincristine inside an orthotopic mouse sarcoma model decreases tumor growth. J Pediatr Surg 2016;51:2058-62.

101. VAN Noord RA, Thomas T, Krook M, Chukkapalli S, Hoenerhoff MJ, Dillman JR, Lawlor ER, Opipari VP, Newman EA. Tissue-directed implantation using ultrasound visualization for development of biologically relevant metastatic tumor xenografts. In Vivo 2017;31:779-91.

102. Sirsi SR, Flexman ML, Vlachos F, Huang J, Hernandez SL, Kim HK, Johung TB, Gander JW, Reichstein AR, Lampl BS, Wang A, Hielscher AH, Kandel JJ, Yamashiro DJ, Borden MA. Contrast ultrasound imaging for identification of early responder tumor models to anti-angiogenic therapy. Ultrasound Med Biol 2012;38:1019-29.

103. van der Ent W, Jochemsen AG, Teunisse AF, Krens SF, Szuhai K, Spaink HP, Hogendoorn PC, Snaar-Jagalska BE. Ewing sarcoma inhibition by disruption of EWSR1-FLI1 transcriptional activity and reactivation of p53. J Pathol 2014;233:415-24.

104. El-Naggar AM, Veinotte CJ, Cheng H, Grunewald TG, Negri GL, Somasekharan SP, Corkery DP, Tirode F, Mathers J, Khan D, Kyle AH, Baker JH, LePard NE, McKinney S, Hajee S, Bosiljcic M, Leprivier G, Tognon CE, Minchinton AI, Bennewith KL, Delattre O, Wang Y, Dellaire G, Berman JN, Sorensen PH. Translational activation of HIF1 $\alpha$ by YB-1 promotes sarcoma metastasis. Cancer Cell 2015;27:68297.

105. Franzetti GA, Laud-Duval K, van der Ent W, Brisac A, Irondelle M, Aubert S, Dirksen U, Bouvier C, de Pinieux G, Snaar-Jagalska E, Chavrier P, Delattre O. Cell-to-cell heterogeneity of EWSR1-FLI1 activity determines proliferation/migration choices in Ewing sarcoma cells. Oncogene 2017;36:3505-14.

106. Oyama R, Takahashi M, Yoshida A, Sakumoto M, Takai Y, Kito F, Shiozawa K, Qiao Z, Arai Y, Shibata T, Araki Y, Endo M, Kawai A, Kondo T. Generation of novel patient-derived CIC-DUX4 sarcoma xenografts and cell lines. Sci Rep 2017;7:4712.

107. Murakami T, Singh AS, Kiyuna T, Dry SM, Li Y, James AW, Igarashi K, Kawaguchi K, DeLong JC, Zhang Y, Hiroshima Y, Russell T, Eckardt MA, Yanagawa J, Federman N, Matsuyama R, Chishima T, Tanaka K, Bouvet M, Endo I, Eilber FC, Hoffman RM. Effective molecular targeting of CDK4/6 and IGF-1R in a rare FUS-ERG fusion CDKN2A-deletion doxorubicin-resistant Ewing's sarcoma patientderived orthotopic xenograft (PDOX) nude-mouse model. Oncotarget 2016;7:47556-64.

108. TK216 in Patients With Relapsed or Refractory Ewing Sarcoma. ClinicalTrials.gov Identifier: NCT02657005. Available from: https:// clinicaltrials.gov/ct2/show/NCT02657005 [Last accessed on 23 May 2018].

109. Gorthi A, Romero JC, Loranc E, Cao L, Lawrence LA, Goodale E, Iniguez AB, Bernard X, Masamsetti VP, Roston S, Lawlor ER, Toretsky JA, Stegmaier K, Lessnick SL, Chen Y, Bishop AJR. EWS-FLI1 increases transcription to cause R-loops and block BRCA1 repair in Ewing sarcoma. Nature 2018;555:387-91.

110. Olaparib in Adults With Recurrent/Metastatic Ewing's Sarcoma. ClinicalTrials.gov Identifier: NCT01583543. Available from: https:// clinicaltrials.gov/ct2/show/NCT01583543 [Last accessed on 23 May 2018].

111. ESP1/SARC025 Global Collaboration: A Phase I Study of a Combination of the PARP Inhibitor, Niraparib and Temozolomide or Irinotecan in Patients With Previously Treated, Incurable Ewing Sarcoma. ClinicalTrials.gov Identifier: NCT02044120. Available from: https:// clinicaltrials.gov/ct2/show/NCT02044120 [Last accessed on 23 May 2018].

112. Kontny HU, Hämmerle K, Klein R, Shayan P, Mackall CL, Niemeyer CM. Sensitivity of Ewing's sarcoma to TRAIL-induced apoptosis. Cell Death Differ 2001;8:506-14.

113. Lissat A, Vraetz T, Tsokos M, Klein R, Braun M, Koutelia N, Fisch P, Romero ME, Long L, Noellke P, Mackall CL, Niemeyer CM, Kontny U. Interferon-gamma sensitizes resistant Ewing's sarcoma cells to tumor necrosis factor apoptosis-inducing ligand-induced apoptosis by upregulation of caspase-8 without altering chemosensitivity. Am J Pathol 2007;170:1917-30.

114. de Hooge AS, Berghuis D, Santos SJ, Mooiman E, Romeo S, Kummer JA, Egeler RM, van Tol MJ, Melief CJ, Hogendoorn PC, Lankester AC. Expression of cellular FLICE inhibitory protein, caspase-8, and protease inhibitor-9 in Ewing sarcoma and implications for susceptibility to cytotoxic pathways. Clin Cancer Res 2007;13:206-14.

115. Verhoeven DH, de Hooge AS, Mooiman EC, Santos SJ, ten Dam MM, Gelderblom H, Melief CJ, Hogendoorn PC, Egeler RM, van Tol MJ, Schilham MW, Lankester AC. NK cells recognize and lyse Ewing sarcoma cells through NKG2D and DNAM-1 receptor dependent pathways. Mol Immunol 2008;45:3917-25.

116. Pahl JH, Ruslan SE, Kwappenberg KM, van Ostaijen-Ten Dam MM, van Tol MJ, Lankester AC, Schilham MW. Antibody-dependent cell lysis by NK cells is preserved after sarcoma-induced inhibition of NK cell cytotoxicity. Cancer Immunol Immunother 2013;62:1235-47.

117. Guiho R, Biteau K, Grisendi G, Taurelle J, Chatelais M, Gantier M, Heymann D, Dominici M, Redini F. TRAIL delivered by mesenchymal stromal/stem cells counteracts tumor development in orthotopic Ewing sarcoma models. Int J Cancer 2016;139:2802-11.

118. Berghuis D, Santos SJ, Baelde HJ, Taminiau AH, Egeler RM, Schilham MW, Hogendoorn PC, Lankester AC. Pro-inflammatory chemokinechemokine receptor interactions within the Ewing sarcoma microenvironment determine CD8(+) T-lymphocyte infiltration and affect 
tumour progression. J Pathol 2011;223:347-57.

119. A Phase I Study of NK Cell Infusion Following Allogeneic Peripheral Blood Stem Cell Transplantation From Related or Matched Unrelated Donors in Pediatric Patients With Solid Tumors and Leukemias. ClinicalTrials.gov Identifier: NCT01287104. Available from: https:// clinicaltrials.gov/ct2/show/NCT01287104 [Last accessed on 23 May 2018].

120. Pilot Study of Expanded, Activated Haploidentical Natural Killer Cell Infusions for Sarcomas. ClinicalTrials.gov Identifier: NCT02409576. Available from: https://clinicaltrials.gov/ct2/show/NCT02409576 [Last accessed on 23 May 2018].

121. Phase 2 STIR Trial: Haploidentical Transplant and Donor Natural Killer Cells for Solid Tumors. ClinicalTrials.gov Identifier: NCT02100891. Available from: https:/clinicaltrials.gov/ct2/show/NCT02100891 [Last accessed on 23 May 2018].

122. Haploidentical Stem Cell Transplantation and NK Cell Therapy in Patients With High-risk Solid Tumors. ClinicalTrials.gov Identifier: NCT01807468. Available from: https://clinicaltrials.gov/ct2/show/NCT01807468 [Last accessed on 23 May 2018].

123. Berghuis D, Schilham MW, Vos HI, Santos SJ, Kloess S, Buddingh' EP, Egeler RM, Hogendoorn PC, Lankester AC. Histone deacetylase inhibitors enhance expression of NKG2D ligands in Ewing sarcoma and sensitize for natural killer cell-mediated cytolysis. Clin Sarcoma Res 2012;2:8.

124. Goodison S, Urquidi V. The cancer testis antigen PRAME as a biomarker for solid tumor cancer management. Biomark Med 2012;6:62932.

125. Osterhoff C, Ivell R, Kirchhoff C. Cloning of a human epididymis-specific mRNA, HE6, encoding a novel member of the seven transmembrane-domain receptor superfamily. DNA Cell Biol 1997;16:379-89.

126. Moreaux J, Kassambara A, Hose D, Klein B. STEAP1 is overexpressed in cancers: a promising therapeutic target. Biochem Biophys Res Commun 2012;429:148-55.

127. Evans CH, Liu F, Porter RM, O’Sullivan RP, Merghoub T, Lunsford EP, Robichaud K, Van Valen F, Lessnick SL, Gebhardt MC, Wells JW. EWS-FLI-1-targeted cytotoxic T-cell killing of multiple tumor types belonging to the Ewing sarcoma family of tumors. Clin Cancer Res 2012;18:5341-51.

128. Berghuis D, de Hooge AS, Santos SJ, Horst D, Wiertz EJ, van Eggermond MC, van den Elsen PJ, Taminiau AH, Ottaviano L, Schaefer KL, Dirksen U, Hooijberg E, Mulder A, Melief CJ, Egeler RM, Schilham MW, Jordanova ES, Hogendoorn PC, Lankester AC. Reduced human leukocyte antigen expression in advanced-stage Ewing sarcoma: implications for immune recognition. J Pathol 2009;218:222-31.

129. Park JH, Rivière I, Gonen M, Wang X, Sénéchal B, Curran KJ, Sauter C, Wang Y, Santomasso B, Mead E, Roshal M, Maslak P, Davila M, Brentjens RJ, Sadelain M. Long-term follow-up of CD19 CAR therapy in acute lymphoblastic leukemia. N Engl J Med 2018;378:449-59.

130. Neelapu SS, Locke FL, Bartlett NL, Lekakis LJ, Miklos DB, Jacobson CA, Braunschweig I, Oluwole OO, Siddiqi T, Lin Y, Timmerman JM, Stiff PJ, Friedberg JW, Flinn IW, Goy A, Hill BT, Smith MR, Deol A, Farooq U, McSweeney P, Munoz J, Avivi I, Castro JE, Westin JR, Chavez JC, Ghobadi A, Komanduri KV, Levy R, Jacobsen ED, Witzig TE, Reagan P, Bot A, Rossi J, Navale L, Jiang Y, Aycock J, Elias M, Chang D, Wiezorek J, Go WY. Axicabtagene ciloleucel CAR T-cell therapy in refractory large b-cell lymphoma. N Engl J Med 2017;377:2531-44.

131. Kailayangiri S, Altvater B, Meltzer J, Pscherer S, Luecke A, Dierkes C, Titze U, Leuchte K, Landmeier S, Hotfilder M, Dirksen U, Hardes J, Gosheger G, Juergens H, Rossig C. The ganglioside antigen G(D2) is surface-expressed in Ewing sarcoma and allows for MHCindependent immune targeting. Br J Cancer 2012;106:1123-33.

132. Safety and Efficacy Evaluation of 4th Generation Safety-engineered CAR T Cells Targeting Sarcomas. ClinicalTrials.gov Identifier: NCT03356782. Available from: https://clinicaltrials.gov/ct2/show/NCT03356782 [Last accessed on 23 May 2018].

133. Town J, Pais H, Harrison S, Stead LF, Bataille C, Bunjobpol W, Zhang J, Rabbitts TH. Exploring the surfaceome of Ewing sarcoma identifies a new and unique therapeutic target. Proc Natl Acad Sci U S A 2016;113:3603-8.

134. Ghisoli M, Barve MA, Schneider R, Mennel RG, Lenarsky C, Wallraven G, Kumar P, Nemunaitis D, Roth A, Senzer NN, Fletcher FA, Nemunaitis JJ. Pilot trial of vigil immunotherapy in Ewing's sarcoma. J Clin Oncol 2015;33 suppl 15:abstr10522.

135. Trial of Bi-shRNA-furin and Granulocyte Macrophage Colony Stimulating Factor (GMCSF) Augmented Autologous Tumor Cell Vaccine for Advanced Cancer. ClinicalTrials.gov Identifier: NCT01061840. Available from: https://clinicaltrials.gov/ct2/show/NCT01061840. [Last accessed on 23 May 2018].

136. Vaccine Therapy and Interleukin-2 in Treating Young Patients With Relapsed or Refractory Ewing's Sarcoma or Neuroblastoma. ClinicalTrials.gov Identifier: NCT00101309. Available from: https://clinicaltrials.gov/ct2/show/NCT00101309. [Last accessed on 23 May 2018].

137. A Two-part Phase IIb Trial of Vigil in Ewing's Sarcoma. ClinicalTrials.gov Identifier: NCT02511132. Available from: https://clinicaltrials. gov/ct2/show/NCT02511132. [Last accessed on 23 May 2018].

138. Vakkila J, Jaffe R, Michelow M, Lotze MT. Pediatric cancers are infiltrated predominantly by macrophages and contain a paucity of dendritic cells: a major nosologic difference with adult tumors. Clin Cancer Res 2006;12:2049-54.

139. Long AH, Highfill SL, Cui Y, Smith JP, Walker AJ, Ramakrishna S, El-Etriby R, Galli S, Tsokos MG, Orentas RJ, Mackall CL. Reduction of MDSCs with all-trans retinoic acid improves CAR therapy efficacy for sarcomas. Cancer Immunol Res 2016;4:869-80. 